\title{
The emergence of the entrepreneurial hospital
}

\author{
This article was published in the following Dove Press journal: \\ Innovation and Entrepreneurship in Health \\ 13 April 2015 \\ Number of times this article has been viewed
}

\section{Kyle L Grazier ${ }^{1,2}$ \\ 'Department of Health Management and Policy, School of Public Health, ${ }^{2}$ Department of Psychiatry, School of Medicine, University of Michigan, Ann Arbor, MI, USA}

Correspondence: Kyle L Grazier Department of Health Management and Policy, School of Public Health, University of Michigan, 1420 Washington Heights, Ann Arbor, MI 48109-2029, USA

Tel +l 734936 I222

Fax +I 7347644338

Email kgrazier@umich.edu
Abstract: In creating a vision of the emerging entrepreneurial hospital, this review looks briefly to selected theories used by researchers and practitioners to explore, define, explain, project, and guide hospitals into the future; and then moves directly to how scholars have used those theories to inform their empirical work and explain the findings from that work. The discourse then addresses briefly what might be needed - now - for hospitals to emerge "entrepreneurial" in the future. This article examines some of the academic, professional, and "gray" literature to consider the future of the "hospital". Much of the literature comes from researchers and thought leaders in organizational behavior, social capital, economics, finance, social welfare, health management, and marketing. The paper explores the external environment for hospitals; the effectors, those events and conditions that bear directly on the form and function of the emerging hospital; and the organization-specific and intra-organizational dynamics that help determine how and in what form the hospital will emerge as an entrepreneurial force. While the vision of the "hospital" of the future varies across observers, the theoretical and empirical research, popular discourse, and lessons from other industries and sectors of the economy, provide guidance on why and how knowing what we can know may bring us into the future more effectively and efficiently.

Keywords: health care, innovation, strategy, mission, vision

\section{Introduction}

It is difficult to identify the point in time at which entrepreneurship became a research field and increased in presence in business and education. Drucker noted in the mid 1980s that entrepreneurs exploit change as an opportunity and "create value".,2 Wiklund et al contend that the field of entrepreneurship "has emerged as one of the most vital, dynamic, and relevant in management, economics, regional science, and other social sciences", and yet there are still concerns as to its standing as a research field or a topic within other fields. ${ }^{3}$ Nevertheless, there is a fair amount of consensus that a struggle remains to accept a common definition and boundaries for the term.

In creating a vision of the emerging entrepreneurial hospital, it is, nonetheless, important to posit a working definition or core characteristics of "entrepreneurs" or entrepreneurial enterprises. Drawing heavily from the work of many authors, and summarized by Abu-Saifan, "Entrepreneurs are conceptualized as individuals who see the world differently and envision the future better than others do. They seize opportunities that otherwise would go unnoticed. They perceive and accept risks differently than others". Extracting from the literature on "venture creation, opportunity exploitation, and profit maximization", the author derives a set of core characteristics to include: innovator, high achiever, risk bearer, arbitrageur, value creator, opportunist, initiative 
taker, and leader. Extrapolating from these individualist dimensions, the entrepreneurial organization would be one with a preponderance of individuals with these characteristics and a mission and vision that is deployed through innovative processes and value creation. While this working definition and core characteristics emphasize the economic view of growth maximization, this article also explores other theoretic perspectives and empirical work that expands a vision of an entrepreneurial hospital.

This paper looks briefly to selected theories used by researchers and practitioners to explore, define, explain, project, and guide hospitals into the future; and then moves directly to how scholars have used those theories to inform their empirical work and explain the findings from that work. The discourse then addresses briefly what might be needed now - to emerge "entrepreneurial" in the future. Much of the literature in this area has come from researchers and thought leaders in organizational behavioral, social capital, economics, finance, social welfare, health management, and marketing. The framework for discussion can be viewed as a path to the future environment for the emerging hospital; and the effectors, those events and conditions that bear directly on the form and function of the emerging hospital; and the view from the perspective of the organization-specific and intraorganizational dynamics that help determine how and in what form the hospital will emerge as an entrepreneurial entity.

While the vision of the "hospital" of the future varies across observers, the theoretical and empirical research, popular discourse, and lessons from other industries and sectors of the economy provide guidance on why and how knowing what we can see may bring us into the future more effectively and efficiently.

The search strategy was devised to identify hospital entrepreneurial literature spanning the health sciences and social sciences. Databases searched included PubMed; ProQuest Databases (including ABI/Inform Complete); Health Policy Reference Center; Google Scholar; and Social Science Abstracts. Additional searches were conducted in Google and the Search Engine of Think Tanks from the Kennedy School of Government Library. The database Scopus was used for citation tracking. The intent was to provide an overview of some key concepts in the hospital entrepreneurship literature as opposed to a comprehensive survey. ${ }^{5}$ Although not referencing health or hospitals, recent work by others provide systematized reviews of the entrepreneurship literature. ${ }^{6-9}$

\section{Approach}

The extent to which hospitals emerge from the last halfdecade and use entrepreneurial thinking, strategies, methods, and tools to determine their future, depends on external and internal conditions and effectors. There are many interdependencies among the future hospital's external and internal missions, markets, organizational structure, culture, management expertise, and the potential for change and change management. Theory and empirical research inform current understanding of the future hospital's missions, given future competition for funding, the lack of which may reduce the ability of a hospital to cross subsidize unfunded missions. Future markets for health care will be dynamic, expanding and contracting as the business of hospital care changes; they will be global for much of the market, and more local as personalized medicine is integrated into the scenario of care planning and delivery. Organizational theorists and empiricists posit and test taxonomies for entrepreneurialism in generic organizations, in not-for-profit and for-profit firms, and in hospitals, modified by firm size, location, culture, managerial style, and governance. Inter and intrapersonal and organizational relationships, hierarchies, vertical and horizontal spread describe culture for existing organizations, in an effort to categorize, explain, and predict what form entrepreneurialism might take and how rapidly it will diffuse throughout an institution or system, and then guide owners, communities, managers, and investors in recognizing risks and rewards.

\section{Informative theories}

Theories and concepts from economics related to market competition help identify the possible external pressures facing the future hospital, that include population growth, disease burden, health delivery methods, concentration of markets, globalization of expertise and knowledge, and ease in transportation of technology and people. The growth in entities such as non-traditional radiology companies, or physician-owned specialty hospitals are believed to be a result of aggressive non-traditional competition, fueled by changes in market demands, profit centers, business principles, and economies of scale. Entrepreneurship is believed to play a moderating (albeit curvilinear) effect on the relationships between market orientation and performance for these new entities. ${ }^{10,11}$ Generally, when rapid change is buttressed by entrepreneurial behaviors, growth and sustainability are more likely. ${ }^{12-24}$ The importance of the economic perspective on entrepreneurship is supported by early work of Drucker, ${ }^{1}$ and more recent work by Shane and Venkataraman; ${ }^{8}$ but it is not the only useful perspective when considering the entrepreneurial hospital. ${ }^{25}$ Public sector entrepreneurship and social entrepreneurship concepts contribute "mission" and "value" as motivators of entrepreneurial thinking and behavior for 
the hospital of the future. ${ }^{26-28}$ Public sector and not-for-profit entrepreneurship theories suggest the community, the public good, and social welfare as direct or mediated influencers on the effectiveness and outcomes of entrepreneurialism in shaping the emerging hospital. Social entrepreneurship is viewed by some as the basis of successful value creation aimed at solving social problems. The constructs capture the many roles of innovation in achieving greater social impact. ${ }^{13,19,21,22,29-34}$ Drawing on the organizational identity literature, a study of award-winning social ventures demonstrated that these social ventures:

[...] exhibit dual identities - a utilitarian organizational identity (ie, entrepreneurial, product oriented) and a normative organizational identity (ie, social, people oriented). Further, when compared with the mission statements of other high-performing entrepreneurial enterprises [...] analysis suggests that social ventures manifest a greater normative identity and an equivalent utilitarian identity. ${ }^{27}$

Cultural competence, that is, the degree which organizations are predisposed to detect and fill gaps between market desires and market offerings, does not necessarily mean that social entrepreneurial endeavors are altruistically motivated. Not all social ventures start with the "intention of creating social value, but with the question: How can I make a profit". ${ }^{30}$ A recently proposed paradigm called effectual entrepreneurship focuses on existing or available resources, rather than identifying opportunities first. For hospitals and other organizations, using this paradigm requires leaders to "foster a culture that questions the status quo". ${ }^{32}$

\section{Intra-organizational constructs}

Theorists and thought leaders contribute to our understanding of what the emerging hospital as an institution might become with careful viewing of its intra- and extra-organizational structure and behavior, dynamic capabilities, strategic management, and asset orchestration. ${ }^{34-38}$

Hospital cultures are delicate and complex milieus of "difficult to imitate assets", particularly knowledge, and "difficult - to - replicate enterprise capabilities", both requiring "excellent orchestration" for sustainable success. ${ }^{36}$ Innovation and entrepreneurship in management, strategy, and governance gird enterprise performance. Many anticipated and unanticipated changes in health care delivery result in organizational transformations. These stand to threaten cultures. ${ }^{39}$ For instance, innovations that accompany such major transitions as medical homes (or their next embodiment) with their less provider-centric focus to more team-based and patient centeredness, can threaten organizational culture, resulting in provider dissatisfaction with many aspects of the work and the workplace. ${ }^{40}$ Understanding these and other threats to cultural stability that arise in entrepreneurial firms can lead to proactive means to manage expectations and relationships. ${ }^{41}$ Strategic human resource management has been shown to facilitate new product introductions in entrepreneuriallyoriented firms, and facilitate more prominently in more uncertain environments. ${ }^{37}$ Empirical work, using both qualitative and quantitative methods, shows how aspects of general organizational culture in hospitals relate to patient safety, and how entrepreneurial orientation (EO) within hospitals motivates and protects staff and patients. ${ }^{42}$

In attempting to understand entrepreneurial behavior within organizations driven and not driven by profit motives, researchers have explored the role of governance, particularly as it is exhibited in boards of directors. Resource based theory and $\mathrm{EO}$ research look to boards as a strategic resource shaping EO and performance. A report of the International Bioethics Committee of UNESCO on Social Responsibility and Health addressed social responsibility in the context of health care delivery, suggesting a new paradigm in hospital governance. They concluded that, "adequate corporate governance and corporate strategy are the gold standard of social responsibility". This new governance approach creates organizational value through "performance, conformance and responsibility". ${ }^{29}$

Decades of research on EO of firms, teams, and organizational leaders have suggested robust relationships between entrepreneurialism and firm performance. ${ }^{6,12,39,43,44}$ There appears to be direct linkages, but also mediators of the relationship between EO and performance, as in the case of absorptive capacity as a moderator of the relationship between EO and firm performance. ${ }^{44}$ In other research, EO and sales growth is mediated by high performance work systems and a partnership philosophy. ${ }^{45}$ Firm level EO needs to be an antecedent to enterprise learning processes, highlighting the relevance of innovativeness, proactiveness, and risk-taking. ${ }^{12}$ EO research also informs organizational strategy and performance; recently, researchers have explored how and why EO pervades organizations; three models examine the role of EO vertically across hierarchical units, horizontally across business units, and temporally as an organization develops. ${ }^{46}$

Researchers focus on other perspectives to understand and prescribe behaviors that lead to innovation and to performance. Research in Spain found that "marketing, management, and product innovation" actions provide the best performance of companies. ${ }^{16}$ Research on not-for-profits, specifically, found that behavioral orientations that lead to 
higher levels of entrepreneurship affect social performance, but not financial performance. ${ }^{47}$

When the view from the hospital pans across the galaxies of industries with potential to advance much, if not all, of our understanding of health, health care, organizations, and definitions of "success", one sees meteoric trajectories. Universities, investment houses, incubators, and industry report substantial and sustained increases in activity. A review of reports from the past year reveals that the ideas, technologies, clinical trials, and patent development involved in these efforts are innovative, rapidly developing, or in advanced stages of development, and will have significant impact on how and where care is delivered a decade from now. Some examples of these initiatives include the following: collaboration between "Brigham and Women's Hospital (BWH) and Dana-Farber Cancer Institute (DFCI) to build new drug-device combinations where they have utilized nanomedicine technologies to develop a drug-delivery system that can precisely target and attack cancer cells"; new "technologies for minimally invasive medical devices for surgery, resulting in shorter hospitalization times and reduced therapy requirements"; new types of "tests including esoteric, public health, anatomic technology, genomic testing, mass spectrophotometry, and other new technologies"; the "development of bioabsorbables for reduction of post-operative adhesions"; "carotid and brain stents as minimally invasive procedures that replace surgical procedures"; emerging "breast cancer personalized and predictive diagnostic tests, particularly with regard to companion tests, tumor markers, and gene profiling assays relevant for breast cancer prognosis and diagnosis". ${ }^{48-54}$ By drawing together care and research in new ways, the entrepreneurial hospital promises increased capacity for biomedical, communication, technological, and yet-to-be-discovered innovation.

\section{The process}

How does the entrepreneurial hospital "emerge"? Experts advise on the need for entrepreneurial education among leaders, managers, clinicians, academic medical centers, and industries now associated with health and health care, and other fields not yet aware of their future relationships. ${ }^{17,20,55-62}$ Just as physician entrepreneurs create organizations that can respond quickly to the financial incentives of the current hospital payment systems, the emerging hospital will need to be nimble and deliberate in using innovation to fund unfunded social missions. ${ }^{19} \mathrm{~A}$ key task of the entrepreneurial hospital is to invent and mediate new uses for its care infrastructure and the unique resource constituted by patient populations. Yet, as it invents and mediates new uses for patient populations and health care infrastructure, the entrepreneurial hospital stands to significantly redefine both systems of care and the bonds of social solidarity. ${ }^{63}$

\section{Acknowledgment}

Judith Smith, informationist at the University of Michigan, for her valuable assistance in directing and consulting on the search of the literature.

\section{Disclosure}

The author reports no conflicts of interest in this work.

\section{References}

1. Drucker PF. Innovation and Entrepreneurship: Practice and Principles. 1st ed. Oxford: Elsevier; 1985.

2. Drucker PF. The discipline of innovation. Harv Bus Rev. 1985;63(3): $67-72$.

3. Wiklund J, Davidsson P, Audretsch DB, Karlsson C. The future of entrepreneurship research. entrepreneurship: Entrepreneurship: Theory and Practice. 2011;35(1):1-9.

4. Abu-Saifan S. Social entrepreneurship: Definition and boundaries. Technology Innovation Management Review. Feb 2012.

5. Grant MJ, Booth A. A typology of reviews: An analysis of 14 review types and associated methodologies. Health Info Libr J. 2009;26(2): 91-108.

6. Rauch A, Wiklund J, Lumpkin GT, Frese M. Entrepreneurial orientation and business performance: An assessment of past research and suggestions for the future. Entrepreneurship: Theory and Practice. 2009;33(3):761-787.

7. McCosh JG. A strategic analysis of the hospital industry and HCA incorporated. Journal of Applied Management and Entrepreneurship. 2003;8(2):120-142.

8. Shane S, Venkataraman S. The promise of entrepreneurship as a field of research. Academy Of Management Review. 2000;25(1):217-226.

9. Trybou J, De Regge M, Gemmel P, Duyck P, Annemans L. Effects of physician-owned specialized facilities in health care: A systematic review. Health Policy. 2014;118(3):316-340.

10. Bhuian SN, Menguc B, Bell SJ. Just entrepreneurial enough: The moderating effect of entrepreneurship on the relationship between market orientation and performance. Journal of Business Research. 2005;58: 9-17.

11. Babu MA, Rosenow JM, Nahed BV. Physician-owned hospitals, neurosurgeons, and disclosure: Lessons from law and the literature. Neurosurgery. 2011;68(6):1724-1732.

12. Brettel M, Rottenberger JD. Examining the link between entrepreneurial orientation and learning processes in small and medium-sized enterprises. J Small Bus Manage. 2013;51(4):471-490.

13. Clark C, Brennan L. Entrepreneurship with social value: A conceptual model for performance measurement. Academy of Entrepreneurship Journal. 2012;18(2):17-40.

14. Cutler D. Where are the health care entrepreneurs? the failure of organizational innovation in health care. In: Lerner J, Stern S, editors. Innovation Policy and the Economy, Volume 11. University of Chicago Press; 2011:1-28.

15. Fasano P. Transforming Health Care the Financial Impact of Technology, Electronic Tools, and Data Mining. Hoboken, New Jersey: John Wiley \& Sons, Inc.; 2013.

16. García-Zamora E, González-Benito O, Muñoz-Gallego PA. Organizational and environmental factors as moderators of the relationship between multidimensional innovation and performance. Innovation: Management, Policy and Practice. 2013;15(2):224-244.

17. Gilmartin MJ. Principles and practices of social entrepreneurship for nursing. J Nurs Educ. 2013;52(11):641-644. 
18. Badlani N, Boden S, Phillips F. Orthopedic specialty hospitals: Centers of excellence or greed machines? Orthopedics. 2012;35(3): e420-e425.

19. Hadley J, Zuckerman S. Physician-owned specialty hospitals: A market signal for medicare payment revisions. Health Aff (Millwood). 2005;Suppl Web Exclusives:W5-491-3.

20. Itri JN, Ballard DH, Kantartzis S, et al. Entrepreneurship in the academic radiology environment. Acad Radiol. 2015;22(1):14-24.

21. Liu SS, Lu JF, Guo KL. Using a social entrepreneurial approach to enhance the financial and social value of health care organizations. $J$ Health Care Finance. 2014;40(3):31-46.

22. Matthews JH. Entrepreneurship in the public sector: New possibilities? In Davidsson, Australian Centre for Entrepreneurship Research Exchange Conference Proceedings; 2014; Queensland University of Technology, Sydney, NSW, pp 804-814.

23. Muroff LR. National entrepreneurial radiology initiatives: What are they, and what can they do to and for you? JAm Coll Radiol. 2013;10(4): 247-252.

24. Perry JE. Physician-owned specialty hospitals and the patient protection and affordable care act: Health care reform at the intersection of law and ethics. American Business Law Journal. 2012;49(2):369.

25. Abdiweli Ali. Unvarnished views of a "radical" economist: Walter E. Williams on more innovation, less regulation, and the entrepreneur as an American hero. Journal of Applied Management and Entrepreneurship 2005;10(3):97-105.

26. Lawrence P. Enterprise in Action: A Guide to Entrepreneurship. New York, NY, USA: John Wiley \& Sons; 2013.

27. Moss TW, Short JC, Payne GT, Lumpkin GT. Dual identities in social ventures: An exploratory study. Entrepreneurship Theory and Practice. 2011;35(4):805-830.

28. Saroj U, Mehndiratta V. Entrepreneurship development and management. Chandigarh, IND: Abhisek Publications; 2009.

29. Brandão C, Rego G, Duarte I, Nunes R. Social responsibility: A new paradigm of hospital governance? Health Care Anal. 2013;21(4): 390-402.

30. Hult GTM, Snow CC, Kandemir D. The role of entrepreneurship in building cultural competitiveness in different organizational types. Journal of Management. 2003;29(3):401-426.

31. Jurik NC, Bodine R. Social responsibility and altruism in small-and medium-sized innovative businesses. Journal of Sociology and Social Welfare. 2014;41(4):113-141.

32. Parris DL, McInnis-Bowers C. Social entrepreneurship questioning the status quo: Waste as a resource. Journal of Economic Issues (ME Sharpe Inc). 2014;48(2):359-366.

33. Weerawardena J, Mort GS. Competitive strategy in socially entrepreneurial nonprofit organizations: Innovation and differentiation. Journal of Public Policy and Marketing. 2012;31(1):91-101.

34. Wilson RC. When entrepreneurship and ethics collide: The case of physician-owned specialty hospitals. Journal of Applied Management and Entrepreneurship. 2008;13(2):87-101.

35. Hess ED. Growing an Entrepreneurial Business: Concepts and Cases. Palo Alto, CA, USA: Stanford University Press; 2011.

36. Teece DJ. Dynamic Capabilities and Strategic Management: Organizing for Innovation and Growth. Oxford, GBR: OUP Oxford; 2009.

37. Wei LQ. The impact of human resource management practices in the entrepreneurial process: evidence from China. Journal of General Management. 2013;38(3):73-89.

38. Wilson A, Whitaker N, Whitford D. Rising to the challenge of health care reform with entrepreneurial and intrapreneurial nursing initiatives. Online J Issues Nurs. 2012;17(2):5.

39. Koelewijn WT, Ehrenhard ML, Groen AJ, van Harten WH. Intraorganizational dynamics as drivers of entrepreneurship among physicians and managers in hospitals of western countries. Soc Sci Med. 2012;75(5):795-800.

40. Scammon DL, Tabler J, Brunisholz K, et al. Organizational culture associated with provider satisfaction. J Am Board Fam Med. 2014;27(2): 219-228.
41. Monsen E, Wayne Boss R. The impact of strategic entrepreneurship inside the organization: Examining job stress and employee retention. Entrepreneurship: Theory and Practice. 2009;33(1):71-104.

42. Singer SJ, Falwell A, Gaba DM, et al. Identifying organizational cultures that promote patient safety. Health Care Manage Rev. 2009;34(4): 300-311.

43. Davis JA, Marino LD, Vecchiarini M. Exploring the relationship between nursing home financial performance and management entrepreneurial attributes. Adv Health Care Manag. 2013;14:14-165.

44. Engelen A, Kube H, Schmidt S, Flatten TC. Entrepreneurial orientation in turbulent environments: The moderating role of absorptive capacity. Research Policy. 2014;43(8):1353-1369.

45. Messersmith JG, Wales WJ. Entrepreneurial orientation and performance in young firms: The role of human resource management. International Small Business Journal. 2013;31(2):115-136.

46. Wales W, Monsen E, Mckelvie A. The organizational pervasiveness of entrepreneurial orientation. Entrepreneurship: Theory and Practice. 2011;35(5):895-923.

47. Coombes SMT, Morris MH, Allen JA, Webb JW. Behavioural orientations of non-profit boards as a factor in entrepreneurial performance: Does governance matter? Journal of Management Studies. 2011;48(4):829-856.

48. Global market for biometrics slated for high growth through 2012 according to BCC research. Health and Medicine Week. 2007:4604 Available from: http:/go.galegroup.com/ps/i.do?id=GALE\%7CA21 $4261133 \& v=2.1 \& u=1 o m \_u m i c h a n n a \& i t=r \& p=A O N E \& s w=w \& a s i d=$ 79ce79f48f6d7a11fef6c3430081a4d0. Accessed March 10, 2015.

49. BCC forecasts rapid growth for bioplastics. Chemical Business Newsbase. 2010. Available from: http://bi.galegroup.com.proxy.lib. umich.edu/global/article/GALE\%7CA244712542/6aefdac6a4516f15c 7f14410ede3a8e1?u=lom_umichanna. Accessed December 24, 2014.

50. BCC research. Advanced Materials and Processes. 2012;170(3):18. Available from: http://www.asminternational.org/web/ims/news/amp/-/ journal_content/56/10192/AMP17003P18/PERIODICAL-ARTICLE. Accessed December 24, 2014.

51. Drug discovery technologies, BCC research. PR Newswire. 2012. Available from: http://search.proquest.com.proxy.lib.umich.edu/docview/10 38068173 . accountid=14667. Accessed December 24, 2014

52. BCC research forecasts the market for disabled and elderly assistive technologies to reach $\$ 60.5$ bn in 2018. Chemical Business Newsbase. 2013. Available from: http://bi.galegroup.com.proxy.lib.umich.edu/ global/article/GALE\%7CA338590754/b477a34acd518b6ecf08daaaa a863021?u=lom_umichanna. Accessed December 24, 2014.

53. Point of care diagnostics, BCC research. PR Newswire. 2014. Available from: http://proxy.lib.umich.edu/login?url=http://search.proquest.com. proxy.lib.umich.edu/docview/1611725849?accountid=14667. Accessed December 24, 2014.

54. Anonymous. BCC sees imaging chemicals growing. Chemical Market Reporter. 1999;255(25):17. Available from: http://search.proquest.com. proxy.lib.umich.edu/docview/194742483?accountid=14667. Accessed December 24, 2014.

55. DePasse JW, Chen CE, Sawyer A, Jethwani K, Sim I. Academic medical centers as digital health catalysts. Healthcare. 2014;2(3):173-176.

56. Elango B, Hunter GL, Winchell M. Barriers to nurse entrepreneurship: A study of the process model of entrepreneurship. J Am Acad Nurse Pract. 2007;19(4):198-204.

57. Gibson T. The entrepreneurial rationalities of governing and the construction of the enterprising nurse. Qual Health Res. 2013;23(1):93-104.

58. Huff C. Are your docs management ready? Hosp Health Netw. 2010;84(4):20-3, 2.

59. Nambudiri V, Adler DS, Wright SC, Lee TH Jr, Loscalzo J, Katz JT. Training the physician executives of the future: The medical management leadership track at Brigham and Women's hospital department of medicine. Physician Executive. 2013;39(3):96-98.

60. Ostrovsky A, Barnett M. Accelerating change: Fostering innovation in healthcare delivery at academic medical centers. Healthcare. 2014;2(1) 9-13. 
61. Rey-Rocha J, López-Navarro I. The fourth mission of hospitals and the role of researchers as innovation drivers in the public healthcare sector. Revista Espanola de Documentacion Cientifica. 2014;37(1).

62. Sharp DB, Monsivais D. Decreasing barriers for nurse practitioner social entrepreneurship. J Am Assoc Nurse Pract. 2014;26(10):562-566.
63. French M, Miller FA. Leveraging the "living laboratory": On the emergence of the entrepreneurial hospital. Soc Sci Med. 2012;75(4): $717-724$.

\section{Publish your work in this journal}

Innovation and Entrepreneurship in Health is an international, peer reviewed, open access journal publishing original research, reports, reviews and commentaries on innovation and entrepreneurship in health. Special focus will be given to the theory, process, and practice of innovation and entrepreneurship by individuals and organizations within the health care context globally. The manuscript management system is completely online and includes a very quick and fair peer review system, which is all easy to use. Visit http://www.dovepress.com/ testimonials.php to read real quotes from published authors.

Submit your manuscript here: http://www.dovepress.com/innovation-and-entrepreneurship-in-health-journal 